\title{
Effect of Activated Carbon on Rooting of Tissue Culture Seedlings of Qiuzi Pear
}

Luan Xiaolong, Shi Hao, Xu Bo, Zhang Qiannan, Liu Li $\square$

College of Horticulture, Anhui Agricultural University, Hefei, 230036, China

$\triangleright$ Corresponding author email: liulireal@ahau.edu.cn

Molecular Plant Breeding, 2021, Vol.12, No.10 doi: $10.5376 / \mathrm{mpb} .2021 .12 .0010$

Received: 01 Mar., 2021

Accepted: 12 Mar., 2021

Published: 25 Mar., 2021

Copyright $\odot 2021$ Luan et al., This article was first published in Molecular Plant Breeding in Chinese, and here was authorized to translate and publish the paper in English under the terms of Creative Commons Attribution License, which permits unrestricted use, distribution, and reproduction in any medium, provided the original work is properly cited.

Preferred citation for this article:

Luan X.L., Shi H., Xu B., Zhang Q.N., and Liu L. 2021, Effect of activated carbon on rooting of tissue culture seedlings of Qiuzi pear, Molecular Plant Breeding, 12(10): 1-7 (doi: 10.5376/mpb.2021.12.0010)

\begin{abstract}
In order to improve the rooting rate of Qiuzi pear tissue culture seedlings, this study took 'sorb' as experimental material, based on Qiuzi pear rooting tissue culture medium (1/2MS+IBA $0.5 \mathrm{mg} / \mathrm{L})$, and added different concentrations of activated carbon (AC): $0.25 \mathrm{~g} / \mathrm{L}, 0.50 \mathrm{~g} / \mathrm{L}, 0.75 \mathrm{~g} / \mathrm{L}, 1.00 \mathrm{~g} / \mathrm{L}$. The results showed that the rooting rate, rooting number and root length of tissue culture seedlings cultured with activated carbon were significantly higher than those of the control group. The most suitable medium for rooting Qiuzi pear was 1/2MS+IBA $0.5 \mathrm{mg} / \mathrm{L}+\mathrm{AC} 1.00 \mathrm{~g} / \mathrm{L}$, and the rooting rate of the treated 'sorb' tissue culture seedlings reached $90 \%$, which could obviously promote the growth of Qiuzi pear tissue culture. The results provide a theoretical basis for improving the rooting rate and survival rate of tissue culture seedlings of pear plants, and provide a reference for the establishment of rapid propagation system of woody plants.
\end{abstract}

Keywords Qiuzi pear; Tissue culture technique; Activated carbon

Autumn pear (Pyrus ussuriensis Maxim.) is one of the important pear species in China, which is abundant in Northeast China, Hebei and Shandong. The seedlings of Qiuzi pear are often cold-resistant rootstocks of pears in orchards, which are excellent raw materials for producing juice drinks and also excellent greening tree species in autumn. The propagation of Qiuzi Pear is mainly carried out by seed propagation and grafting. It takes a long time for seed propagation, and the uniformity of offspring growth is inconsistent. The cultivation time of grafted seedlings is long, the technology is complex, the propagation efficiency is low, the virus is easy to spread quickly, and the degree of genetic heterozygosity is high (Xu et al., 2002). With the development of modern biotechnology, plant tissue culture technology (Xiao and Liu, 2011) can be applied in the rapid propagation of plants, variety improvement and germplasm resources preservation, which can realize the rapid acquisition of high-quality germplasm and contribute to the popularization and demonstration of excellent varieties (Miao et al., 2019). Using plant tissue culture technology, 'sorb' can be propagated rapidly and the seedlings can be consistent. In the traditional plant tissue culture technology, the rooting induction effect of pear is poor. In the research of Liu et al. (2016), the rooting rate of pear tissue culture seedlings is only 33\%. Sun et al. (2015) found that adding activated carbon can improve the rooting quality and rooting rate of emerald pear in the study of tissue rapid propagation technology. In the rooting process of plant tissue culture, activated carbon (AC) can provide a dark environment for rooting, which is beneficial to root induction and root growth, prevent browning, increase the content of soluble protein and total sugar in culture, and adsorb plant growth regulators and substances beneficial to rooting (Sun et al., 2010), thus affecting the culture results. Therefore, by adding different concentrations of activated carbon to rooting medium, this experiment explored the effect of activated carbon on rooting efficiency of tissue culture seedlings, and provided reference and guidance for improving rooting efficiency of pear tissue culture seedlings.

\section{Results and Analysis}

\subsection{Effects of different AC concentrations on the growth of tissue culture seedlings of 'sorb'}

On the $14^{\text {th }}$ day, red young roots appeared in the roots of 'sorb' tissue culture seedlings. With the increase of activated carbon concentration, the number of red young roots increased obviously. On the $21^{\text {st }}$ day, the roots grew 
obviously. On the $28^{\text {th }}$ day (Figure 1), $35^{\text {th }}$ day (Figure 2) and $41^{\text {st }}$ day (Figure 3), the rooting rate and rooting situation in each culture medium were measured.

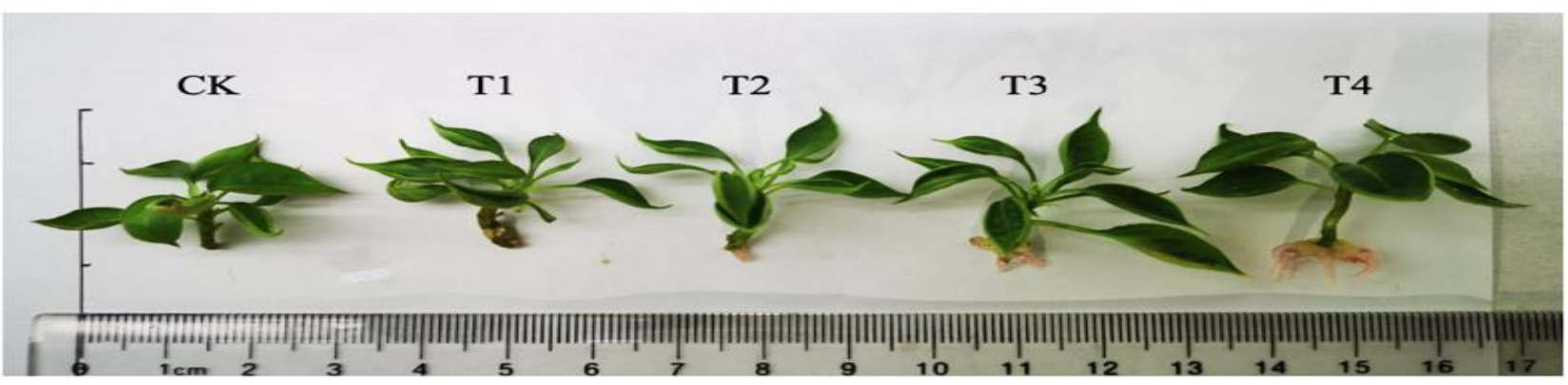

Figure 1 Rooting of 'sorb' seedlings with different AC concentrations on the $28^{\text {th }}$ day

Note: when the concentration of activated carbon is $0.00 \mathrm{~g} / \mathrm{L}$, the rooting status and Length of 'sorb' seedling; T1, when the concentration of activated carbon is $0.25 \mathrm{~g} / \mathrm{L}$, the rooting status and Length of 'sorb' seedling; T2, when the concentration of activated carbon is $0.50 \mathrm{~g} / \mathrm{L}$, the rooting status and Length of 'sorb' seedling; T3, when the concentration of activated carbon is 0.75 $\mathrm{g} / \mathrm{L}$, the rooting status and Length of 'sorb' seedling; $\mathrm{T} 4$, when the concentration of activated carbon is $1.00 \mathrm{~g} / \mathrm{L} / \mathrm{The}$ rooting status and Length of 'sorb' seedlings

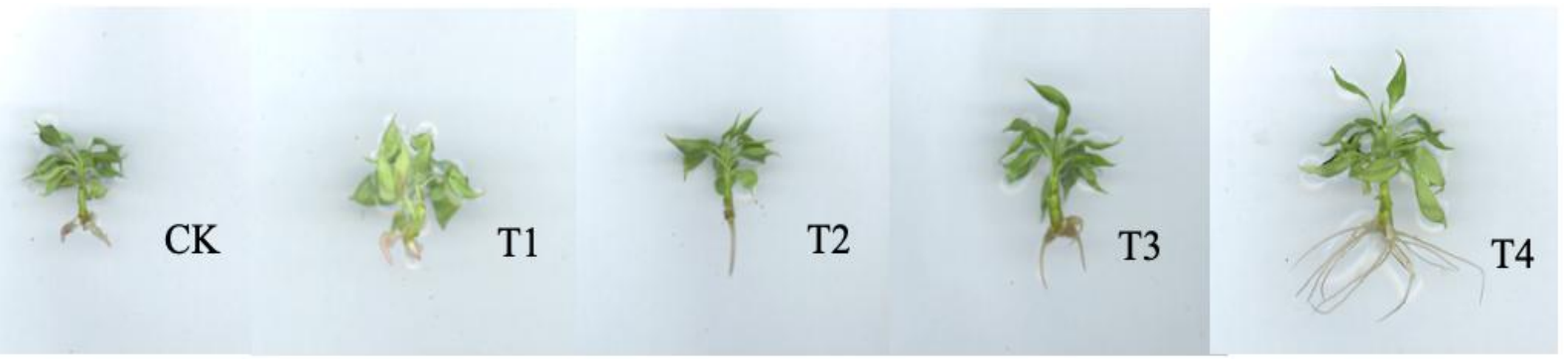

Figure 2 Rooting of 'sorb'seedlings with different AC concentrations on the $35^{\text {th }}$ day

Note: CK, activated carbon concentration is $0.00 \mathrm{~g} / \mathrm{L}$; T1, activated carbon concentration is $0.25 \mathrm{~g} / \mathrm{L}$; T2, activated carbon concentration is $0.50 \mathrm{~g} / \mathrm{L}$; T3, activated carbon concentration is $0.75 \mathrm{~g} / \mathrm{L}$; T4, activated carbon concentration is $1.00 \mathrm{~g} / \mathrm{L}$
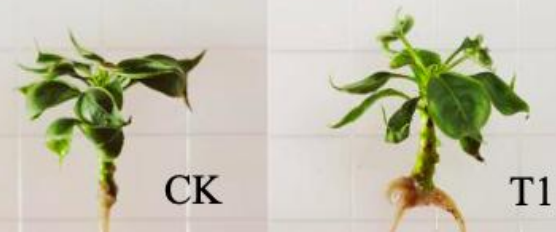

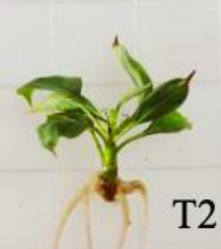

$\mathrm{T} 2$
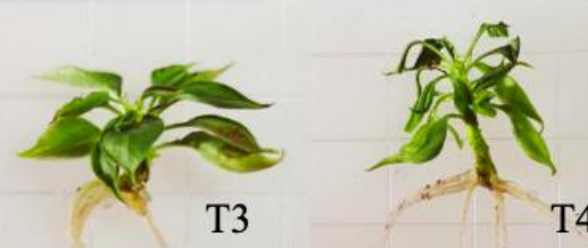

Figure 3 Rooting of 'sorb'seedlings with different AC concentrations on the $41^{\text {st }}$ day

Note: CK, activated carbon concentration is $0.00 \mathrm{~g} / \mathrm{L}$; T1, activated carbon concentration is $0.25 \mathrm{~g} / \mathrm{L}$; T2, activated carbon concentration is $0.50 \mathrm{~g} / \mathrm{L} ; \mathrm{T} 3$, activated carbon concentration is $0.75 \mathrm{~g} / \mathrm{L} ; \mathrm{T} 4$, activated carbon concentration is $1.00 \mathrm{~g} / \mathrm{L}$

\subsection{Effects of different $\mathrm{AC}$ concentrations on rooting rate and rooting number of 'sorb' seedlings in tissue culture}

As shown in Figure 4, on the $41^{\text {st }}$ day of culture, the rooting rates of T2 and T3 were both $50 \%$, T4 was $90 \%$, CK was the lowest, which was $40 \%$. The rooting rates of rooting seedlings cultured with activated carbon were higher than those of the control group. The rooting rate of $\mathrm{T} 1$ was $80 \%$. The rooting rate of $\mathrm{T} 4$ was significantly higher than that of CK, T2 and T3.

In different treatments, there were significant differences in the rooting number of pear tissue culture seedlings, which were 2.2 for T1, 2.2 for T2, 3.6 for T3, 6.2 for T4 and 0.8 for CK. As shown in Figure 5, with the increase of activated carbon concentration, the number of rooting strips increased. T4 was significantly higher than CK, T1 and $\mathrm{T} 2$. 


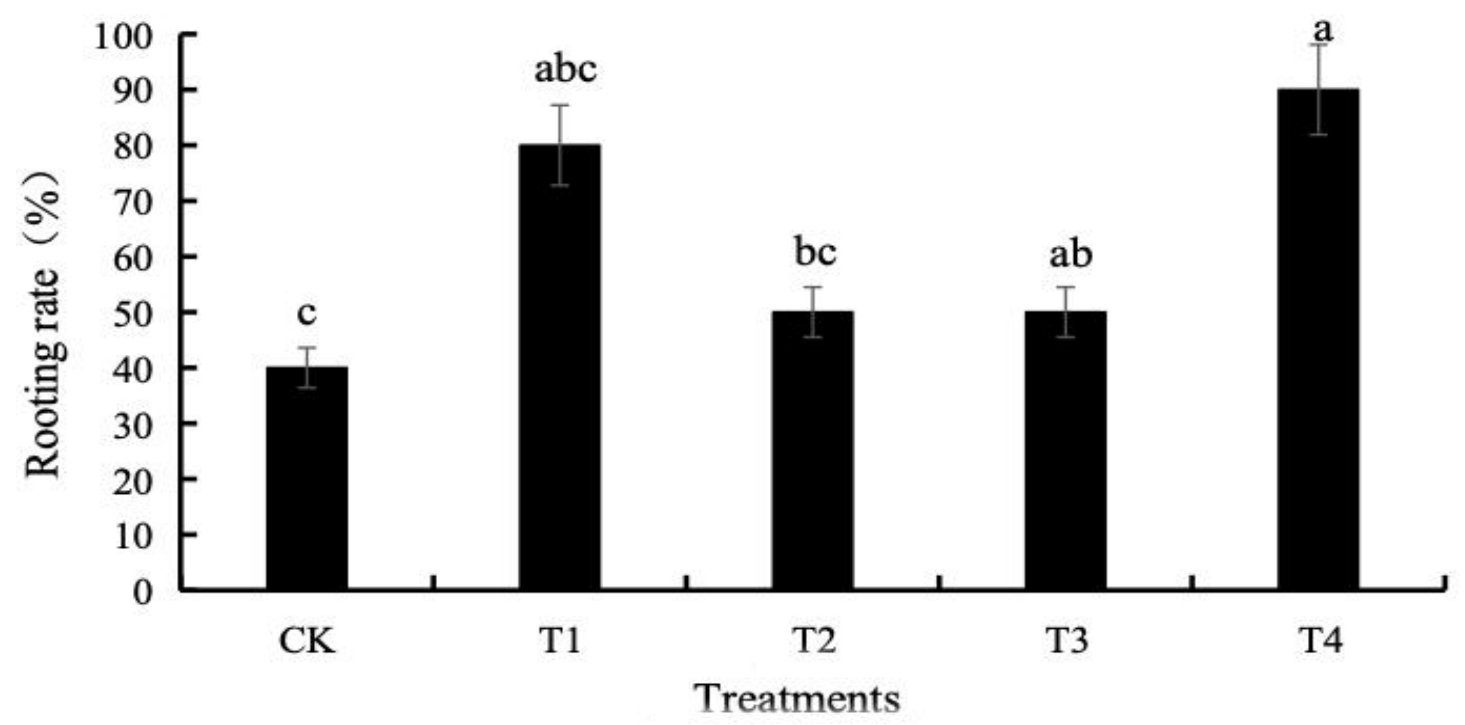

Figure 4 Effects of different AC concentrations on rooting rate of 'sorb' seedlings

Note: $\mathrm{CK}$, activated carbon concentration is $0.00 \mathrm{~g} / \mathrm{L} ; \mathrm{T} 1$, activated carbon concentration is $0.25 \mathrm{~g} / \mathrm{L}$; T2, activated carbon concentration is $0.50 \mathrm{~g} / \mathrm{L} ; \mathrm{T} 3$, activated carbon concentration is $0.75 \mathrm{~g} / \mathrm{L} ; \mathrm{T} 4$, activated carbon concentration is $1.00 \mathrm{~g} / \mathrm{L}$

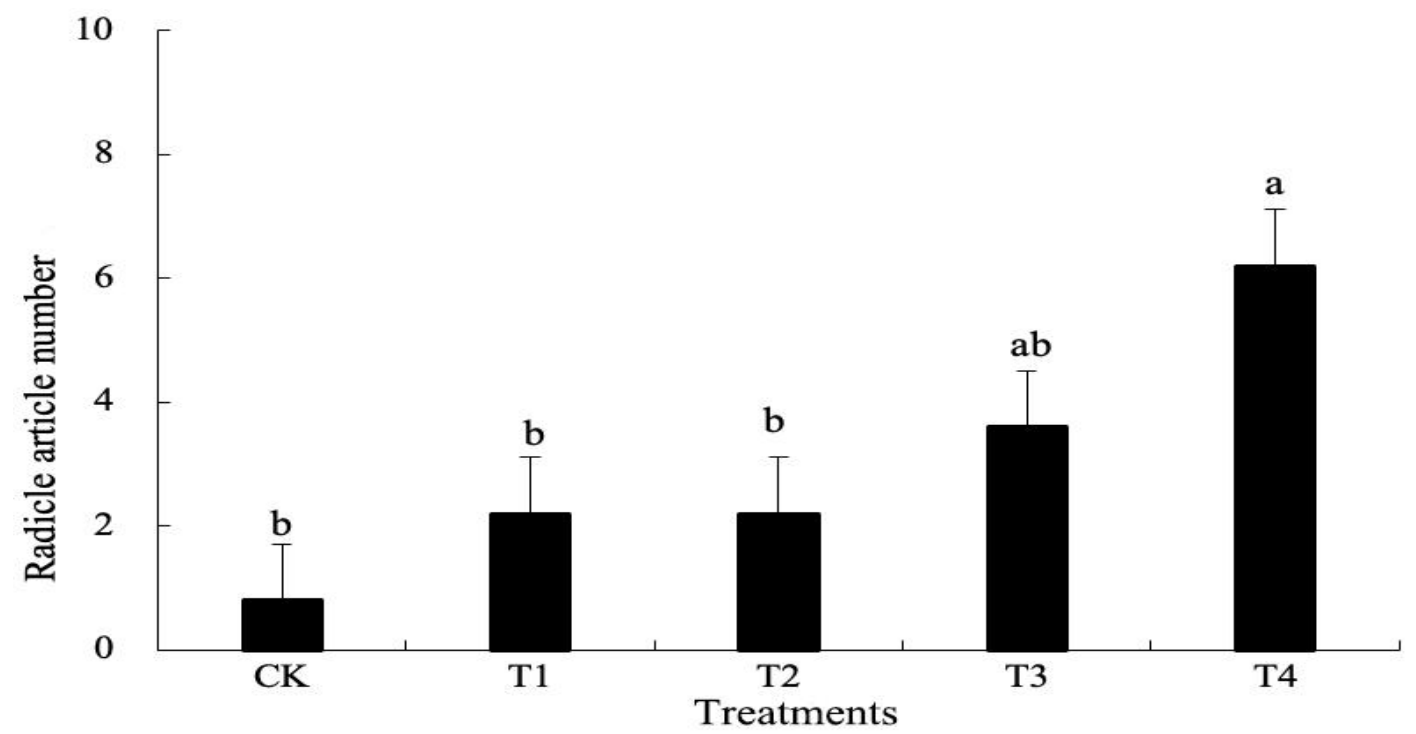

Figure 5 Effects of different AC concentrations on rooting number of 'sorb' seedlings

Note: $\mathrm{CK}$, activated carbon concentration is $0.00 \mathrm{~g} / \mathrm{L}$; T1, activated carbon concentration is $0.25 \mathrm{~g} / \mathrm{L}$; T2, activated carbon concentration is $0.50 \mathrm{~g} / \mathrm{L} ; \mathrm{T} 3$, activated carbon concentration is $0.75 \mathrm{~g} / \mathrm{L} ; \mathrm{T} 4$, activated carbon concentration is $1.00 \mathrm{~g} / \mathrm{L}$

\subsection{Effects of different AC concentrations on root morphological indexes of tissue culture seedlings of 'sorb'}

Measure the average root length of 'sorb' seedlings under different treatments on the $41^{\text {st }}$ day (Figure 6). It can be seen from the figure that the average root length of $\mathrm{T} 4$ is significantly different. Compared with the other four groups of results, the total root length is far greater than other treatments.

As shown in Figure 7, with the increase of AC concentration, the root surface area of 'sorb' seedlings increased. The root surface area of $\mathrm{T} 4$ was significantly higher than that of other treatments.

According to Figure 8, with the increase of AC concentration, the volume of Qiuzi pear seedlings increased. 
Molecular Plant Breeding 2021, Vol.12, No.10, 1-7

http://genbreedpublisher.com/index.php/mpb

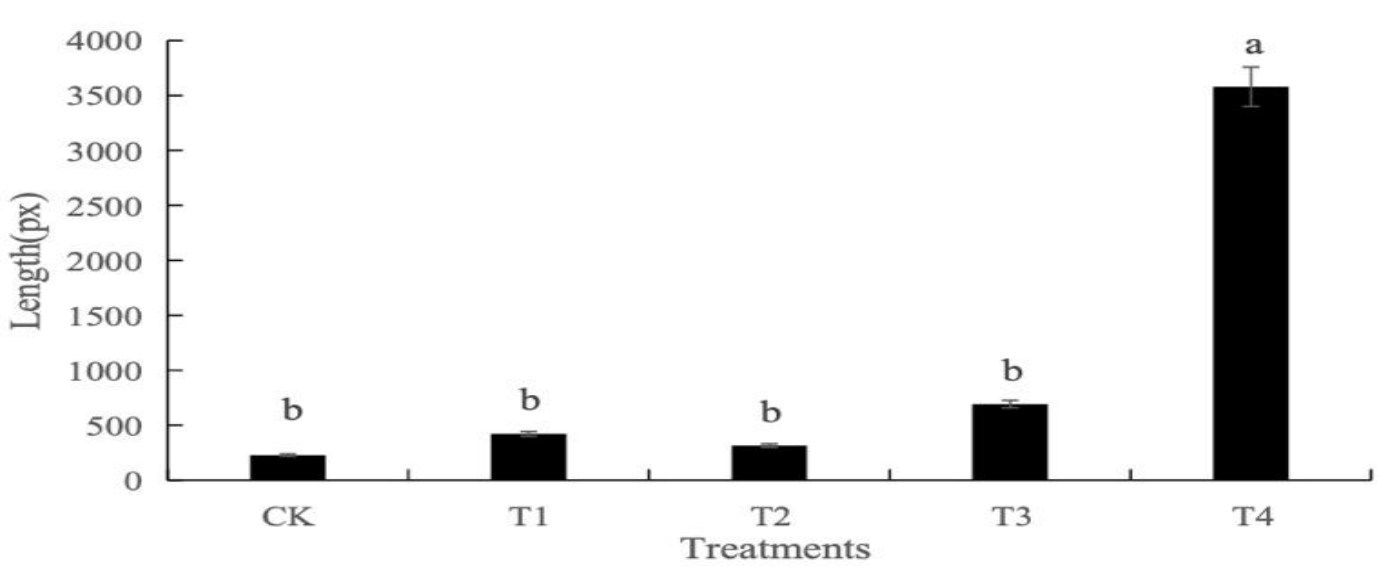

Figure 6 Effects of different AC concentrations on total length of 'sorb' seedlings

Note: CK, activated carbon concentration is $0.00 \mathrm{~g} / \mathrm{L}$; T1, activated carbon concentration is $0.25 \mathrm{~g} / \mathrm{L} ; \mathrm{T} 2$, activated carbon concentration is $0.50 \mathrm{~g} / \mathrm{L} ; \mathrm{T} 3$, activated carbon concentration is $0.75 \mathrm{~g} / \mathrm{L} ; \mathrm{T} 4$, activated carbon concentration is $1.00 \mathrm{~g} / \mathrm{L}$

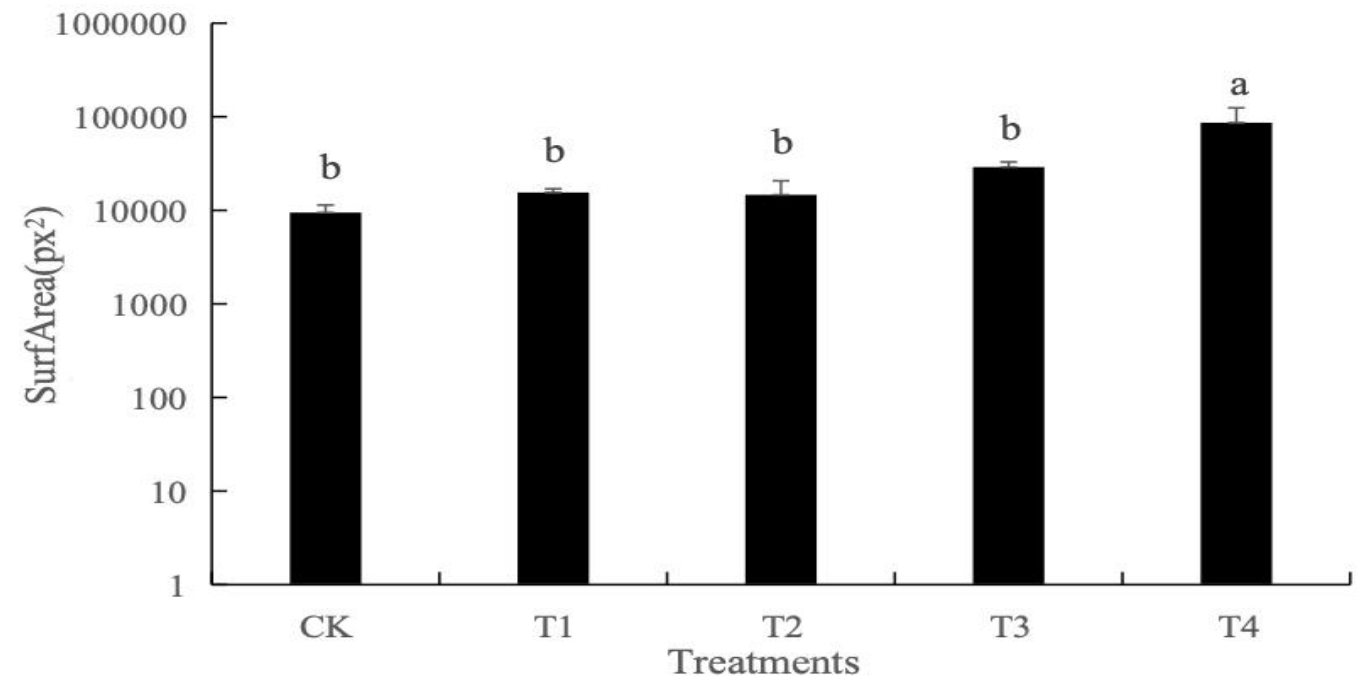

Figure 7 Effects of different AC concentrations on the surface area of 'sorb' seedlings

Note: CK, activated carbon concentration is $0.00 \mathrm{~g} / \mathrm{L}$; T1, activated carbon concentration is $0.25 \mathrm{~g} / \mathrm{L} ; \mathrm{T} 2$, activated carbon concentration is $0.50 \mathrm{~g} / \mathrm{L} ; \mathrm{T} 3$, activated carbon concentration is $0.75 \mathrm{~g} / \mathrm{L} ; \mathrm{T} 4$, activated carbon concentration is $1.00 \mathrm{~g} / \mathrm{L}$

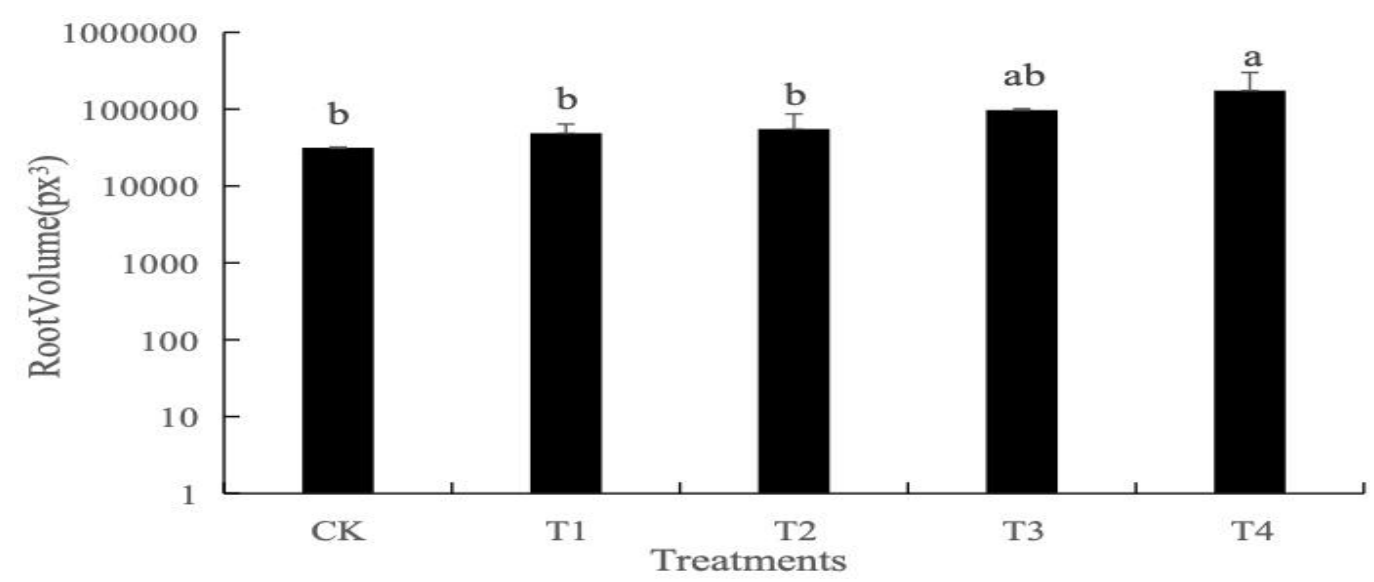

Figure 8 Effects of different AC concentrations on seedling volume of 'sorb'

Note: CK, activated carbon concentration is $0.00 \mathrm{~g} / \mathrm{L}$; T1, activated carbon concentration is $0.25 \mathrm{~g} / \mathrm{L} ; \mathrm{T} 2$, activated carbon concentration is $0.50 \mathrm{~g} / \mathrm{L} ; \mathrm{T} 3$, activated carbon concentration is $0.75 \mathrm{~g} / \mathrm{L} ; \mathrm{T} 4$, activated carbon concentration is $1.00 \mathrm{~g} / \mathrm{L}$ 


\section{Discussion}

During the growth and development of plants, hormones in the body are in a dynamic process, and plant growth regulators can regulate the growth of tissue culture seedlings. Different varieties have different responses to the types and concentrations of growth regulators, and only by choosing appropriate hormone ratio can better proliferation effect be achieved (Xu et al., 2008). Qiu et al. (2015) thought that the most suitable rooting medium for North American pear was MS+TDZ $0.5 \mathrm{mg} / \mathrm{L}+\mathrm{ABT} 1$ \# $1.5 \mathrm{mg} / \mathrm{L}+$ Sucrose $20 \mathrm{~g} / \mathrm{L}+$ Agar $4.5 \mathrm{~g} / \mathrm{L}+\mathrm{AC} 2.0 \mathrm{~g} / \mathrm{L}$, and the rooting rate was $52.03 \%$. Zhang et al. (2009) thought that the most suitable rooting medium for Huangguan pear was $1 / 2 \mathrm{MS}+\mathrm{IBA} 1.0 \mathrm{mg} / \mathrm{L}+$ sucrose $20 \mathrm{~g} / \mathrm{L}$, and the rooting rate was $33 \%$. Wen and Zhang (2007) thought that the most suitable rooting medium was $1 / 2 \mathrm{~ms}+\mathrm{NAA} 1.0 \mathrm{mg} / \mathrm{L}+\mathrm{IBA} 1.0 \mathrm{mg} / \mathrm{L}+\mathrm{AC} 3.0 \mathrm{mg} / \mathrm{L}$, and the rooting rate was $95 \%$. Sun et al. (2001) thought that the medium for strong seedling of Fengshui pear was $1 / 2$ MS+BA $0.5 \mathrm{mg} / \mathrm{L}+\mathrm{GA} 0.5 \mathrm{mg} / \mathrm{L}+3 \%$ sucrose. The experiment found that $1 / 2 \mathrm{MS}+\mathrm{IBA} 0.5 \mathrm{mg} / \mathrm{L}+\mathrm{AC} 1.0 \mathrm{~g} / \mathrm{L}$ was suitable for rooting culture of 'sorb', and the rooting rate was $90 \%$. It is difficult to take root in tissue culture of Pyrus. One of the important factors affecting rooting of tissue culture seedlings is the type and concentration of auxin. IBA, IAA and NAA are commonly used growth regulators to promote rooting. IBA was used for rooting and tissue culture seedlings of seedless Rosa roxburghii (Jiang et al., 2017) and Douli (Li et al., 2012), but the suitable concentration was different. $0.2 \mathrm{mg} / \mathrm{L}$ IBA is suitable for seedless Rosa roxburghii and $1.5 \mathrm{mg} / \mathrm{L} \mathrm{IBA}$ is suitable for bean pear. In this experiment, the rooting of 'sorb' seedlings in tissue culture was studied. The results showed that the most suitable rooting medium for 'sorb' seedlings was $1 / 2 \mathrm{~ms}+\mathrm{IBA} 0.50 \mathrm{mg} / \mathrm{L}+\mathrm{AC} 1.00 \mathrm{~g} / \mathrm{L}$.

Light conditions and culture methods also have effects on adventitious root induction of tissue culture seedlings. Tang et al. (2006) found that early dark culture promoted the rooting induction of 'Zaosu' and 'Shenbuzhi', but had poor rooting induction effect on 'Bali' and 'Komisi'. In this experiment, active carbon was added to provide a dark environment and placed under light conditions, which improved the rooting rate and rooting number of 'sorb'.

Yang et al. (2008) induced Qiuzi pear to take root, the medium was $1 / 2 \mathrm{MS}+\mathrm{IBA} 0.5 \mathrm{mg} / \mathrm{L}$, the rooting rate was $45 \%$, and the number of rooting strips was 3. When Wang et al. (2018) induced Qiuzi pear to take root, the medium was $1 / 2 \mathrm{MS}+\mathrm{IBA} 0.5 \mathrm{mg} / \mathrm{L}$, the rooting rate was $45.5 \%$, and the number of rooting strips was 2.24 . In this experiment, based on the rooting media used in Yang Fang and Wang Defen, activated carbon was added to promote the rooting of 'sorb' seedlings. The effect of the medium added with activated carbon was higher than that without activated carbon in rooting rate, rooting quantity, average root length, surface area and volume. When the concentration of activated carbon was $1 \mathrm{~g} / \mathrm{L}(1 / 2 \mathrm{MS}+\mathrm{IBA} 0.5 \mathrm{mg} / \mathrm{L}+\mathrm{AC} 1.0 \mathrm{~g} / \mathrm{L})$, the rooting rate of 'sorb' seedlings was as high as $90 \%$, and the number of rooting strips was 6.2 . In this study, the efficiency and quality of tissue culture of 'sorb' seedlings were significantly improved by adding activated carbon, which provided reference for the tissue culture technology of fruit trees.

\section{Test Materials and Methods}

\subsection{Test materials}

The tissue culture seedlings of 'sorb' cultivated in Key Laboratory of Fruit Tree, College of Horticulture, Anhui Agricultural University were used as test materials.

\subsection{Culture conditions}

The activated carbon used in this experiment is black powder. When the culture medium is prepared, if it is added in advance, it will agglomerate and adhere to the pot wall. Therefore, it is advisable to add activated carbon after the culture medium melts and before sterilization. It is necessary to constantly shake the culture medium before solidification, so that it can be evenly distributed during solidification. Rooting medium was $1 / 2 \mathrm{MS}+\operatorname{IBA}(0.5$ $\mathrm{mg} / \mathrm{L}$ ) $+\mathrm{AC}$ (activated carbon concentration gradients were $0.25 \mathrm{~g} / \mathrm{L}, 0.50 \mathrm{~g} / \mathrm{L}, 0.75 \mathrm{~g} / \mathrm{L}$ and $1.00 \mathrm{~g} / \mathrm{L}$, respectively). The medium was used after sterilization (sterilized in a sterilization pot at $121^{\circ} \mathrm{C}$ for 20 minutes). The culture temperature is $25^{\circ} \mathrm{C}$, the illumination is $2000 \mathrm{~lx}$, and the illumination time is $24 \mathrm{~h} / \mathrm{d}$. 


\subsection{Test design}

The experiment was conducted in November, 2020, with a single factor randomized block design. Take the tissue culture seedlings of 'sorb' in the same growth condition in the same period, and carry out increment culture on the tissue culture seedlings of 'sorb', and inoculate 2 plants in each bottle, totally inoculating 50 bottles. Taking tissue culture seedlings of 'sorb' as materials, more than one third of petiole was cut, and the petiole was beveled at 45 with a scalpel on an ultra-clean workbench. The cut seedlings of 'sorb' were put into rooting medium containing different concentrations of activated carbon for culture.

\subsection{Index determination}

Electronic vernier caliper and instruments regent scanner calibrated for image analysis with regent instruments software were used for determination and analysis.

Rooting rate $(\%)=($ number of rooted stem segments/number of inoculated stem segments $) \times 100 \%$

Rooting number(number)=total root number of stem segment/stem segment number of rooting

Average root length $(\mathrm{cm})=$ total root length/total number of rooted plants

\subsection{Data analysis}

SPSS software (IBM SPSS statistics 26) was used for data statistical analysis, Duncan method was used for variance analysis and multiple comparison $(p<0.05)$.

\section{Authors' contributions}

Luan Xiaolong is the executor of this experimental study, finishing data and writing the first draft of the paper; Shi Hao participated in experimental design and analysis of experimental results, Xu Bo and Zhang Qiannan participated in some experimental studies, and $\mathrm{Li} \mathrm{Liu} \mathrm{was} \mathrm{the} \mathrm{project} \mathrm{leader,} \mathrm{guiding} \mathrm{the} \mathrm{design} \mathrm{of} \mathrm{experimental} \mathrm{studies} \mathrm{and} \mathrm{the} \mathrm{revision} \mathrm{of} \mathrm{papers.} \mathrm{All} \mathrm{authors} \mathrm{read} \mathrm{and}$ approved to the final manuscript.

\section{Acknowledgements}

This research is carried out by Anhui University Students Innovation and Entrepreneurship Project (S202010364243; XJDC2020399), the national modern agricultural industry technology system construction project (CARS-29-14).

\section{References}

Jang L.Q., Li W.J., Xiao Q.G., Chen W.L., Xu Z.P., Li L., and Fu M., 2017, Study on tissue culture and rapid propagation technology of seedless Rosa roxburghii, Linye Keji Tongxun(Forestry Science and Technology Newsletter), 34(4): 33-36

Li X.G., Wang H.W., Yang Q.S., Lin J., Wang Z.H., Sheng B.L., Li H., Wang H., and Chang Y.H., 2012, Low vitrification tissue culture and rapid propagation technology of bean pear, Jiangsu Nnongye Kexue(Jiangsu Agricultural Science), 40(12): 54-56

Liu X.F., Feng J.R., Liang X.T., Lv W.J., Li W.H., and Fan X.M., 2016, Research on tissue culture of Korla fragrant pear, Shandong Nongye Kexue(Shandong Agricultural Sciences), 48(5): 9-13

Miao R.R., Qiao Y.L., Wu R.Z., Wang L., Shi X.X., and Du G.Q., 2019, Tissue culture and rapid propagation of 'jinxiangmi' and 'Bali', Fenzi Zhiwu Yuzhong(Molecular Plant Breeding), 17(7): 2297-2302

Qiu Y.B., Kang X.Y., Yang Z.Y., Li T., and Zhao Q.Z., 2015, Study on tissue culture and rapid propagation technology of North American bean pear, Nongxue Xuebao(Journal of Agronomy), 5(12): 64-69

Sun Q.R., Sun H.Y., and Liu Q.Z., 2001, Studies on tissue culture and rapid propagation of Fengshui Pear, Luoye Guoshu(Deciduous Fruits), 33(4): 4-5

Sun W.Y., Liu R.N., Zhang S.S., Huang H.F., He A.L., and Yang H.T., 2015, Rooting technique of 'Lvbaoshi' pear tissue culture seedling, Beifang Yuanyi(Northern Horticulture), 37(18): 116-118

Sun Z.Y., Ssun Z.Q., and Cao B., 2010, Role of activated carbon in promoting rooting of tissue culture seedlings, Hunan Nongye Kexue(Hunan Agricultural Science), 7: 3-5

Tang H.R., Liu C.Q., Luo Y., and Wang X.R., 2006, Effects of medium and culture conditions on rooting of four pear genotypes in vitro., Guoshu Xuebao(Fournal of Fruit Science), 23(2): 283-286+316

Wang D.F., Zhang M., Li D.L., Wang R., Ma C.H., and Song J.K., 2016, Construction of efficient regeneration system of Qiuzi pear leaves, Beifang Yuanyi(Northern Horticulture), 38(4): 97-101

Wen H.T., and Zhang C.L., 2007, Study on tissue culture and rapid propagation technology of pineapple, Xiandai Nongye Keji(Modern Agricultural Science and Technology), 19(4): 10,14

Xiao Z.L., and Liu J.F., 2011, Advances in planttissue culture and new technology application, Ningxia Nonglin Keji(Ningxia Journal of Agriculture Forestry Science Tecnology), 52(1): 13-14, 47

Xu J.L., Ma R.J., Yu M.L., and Sen Z.J., 2008, Study on Tissue Culture Propagation Technology of Damas 1869 Plum, Guoshu Xuebao(Journal of Fruit Science), 25(5): 740-743+785 
Molecular Plant Breeding 2021, Vol.12, No.10, 1-7

http://genbreedpublisher.com/index.php/mpb

Xu L.F., Ma F.W., Wang Z.Z., Ren X.L., and Cao X.Y., 2002, In vitro culture and plant regeneration of pear leaves, Yuanyi Xuebao(Acta Horticulturae Sinica), 29(4): 367-368

Yang F., Wang Y., Xu X.F., Han Z.H., and Li T.Z., 2008, Study on Leaf Plant Regeneration of Qiuzi Pear, Zhongguo Guoshu(China Fruits), 3: 13-16+78

Zhang Y.J., Lin J., Cong Y., Li X.G., and Chang Y.H., 2009, Study on tissue culture and rapid propagation technology of Huangguan pear, Jiangsu Nongye Kexue(Jiangsu Agricultural Science), 37(3): 35-36 